\title{
Effect of inoculation with arbuscular mycorrhizas on rooting, weaning and subsequent growth of micropropagated Malus (L.) Moench
}

\author{
Marjatta Uosukainen and Mauritz Vestberg
}

\begin{abstract}
Uosukainen, M. \& Vestberg, M. 1994. Effect of inoculation with arbuscular mycorrhizas on rooting, weaning and subsequent growth of micropropagated Malus (L.) Moench. Agricultural Science in Finland 3: 269-279. (Agricultural Research Centre of Finland, Laukaa Research and Elite Plant Unit, FIN-41340 Laukaa, Finland.)

The importance of different rooting methods and the effects of arbuscular mycorrhizal (AMF) inoculation on the rooting rate, weaning survival and subsequent growth of microcuttings of Malus rootstock YP and the Finnish crab apple cultivars Hanna and Marjatta were studied in four experiments conducted at the Laukaa Research and Elite Plant Unit, Finland. Sucrose in the in vitro rooting medium gave the best support to weaning survival in comparision with glucose and fructose. Directly rooted microcuttings had a higher survival rate than in vitro rooted microcuttings. AMF inoculation did not improve the rooting rate in direct rooting. However, the Glomus hoi strain V98 caused severe rotting of microcuttings and thus lowered the rooting rate of $\mathrm{cv}$. Hanna. AMF inoculation increased the mean shoot height of established plants, particularly inoculation with $G$. hoi V98, G. claroideum V43a or G. fistulosum V128. This effect, however, varied considerably in different host-fungus combinations. Some AMF strains, e.g. G. hoi V104, caused strong growth retardation. After the rooting and weaning stage, many uninoculated plants lapsed into arrest of growth. This phenomenon was less frequent in AMF inoculated plants. Optimal timing of AMF inoculation and nutritional level of rooting and weaning substrate are discussed.
\end{abstract}

Key words: Apple rootstock, crab apple, carbon drain, Glomus claroideum, G. fistulosum, G. hoi, G. mosseae, rooting of microcuttings

\section{Introduction}

The beneficial effect of arbuscular mycorrhizal fungi (AMF) on the growth of plants is well documented (Mosse 1973, HaRley and SMITH 1983). Apple seedlings are usually reported to show a strong positive growth response to inoculation with AMF (BENSON and COVEY 1976, HOEPFNER et al. 1983, GNeKow and Marschner 1989, AN et al. 1993), even at moderate or high phosphorus availability (Plenchette et al. 1981, GNEKOW and MARSCHNER 1989). In micropropagated apple plants AMF may be even more beneficial than in seedlings (GIANINAZZI et al. 1990, BRANZANTI et al. 1992), although there are problems such as high sensitivity of apple microcuttings to rot following inoculation, particularly in direct rooting (Avanzato et al. 1994).

The basic principles in rooting of apple microcuttings are rooting in vitro on agar gelified medium or direct, post vitro rooting on artificial or compost substrate (DIRR and HeUSER 1987). Also combining of these two rooting methods was shown to be successful on rooting of apple microcuttings (ZiMMERMAN and FORDHAM 1985). In rooting of apple microcuttings, there may be large 
fluctuations due to various accidental external factors (DENISSEN et al. 1992). The timing of harvesting shoots from the subculture medium (DE KLerk and Ter Brugge 1992, Uosukainen 1992) and the type of carbohydrate used in a gelified rooting medium (MoNCOUSIN et al. 1992, UosUKAINEN 1992) are crucial. A too long auxin treatment may lead to rooting inhibition and disturbances in the apical growth of micropropagated shoots (GeOrge and SHERrington 1988). Also light, photoperiod, temperature and macronutrients of the rooting medium have an effect on root initiation, root growth and the quality of the root system (ZIMMERMAN and FordHAM 1985, GEORGE and SHERRINGTON 1988).

A good rooting result in the laboratory does not always lead to good weaning and undisturbed continuous growth of the rooted plantlets. There may be great losses after transplanting to soil in greenhouses or in growth chambers (PREECE and SUTTER 1991). Microcuttings, rooted on agar, have difficulty in inducing a fully effective root system when the plants are transferred to soil (DEBERGH and MAENE 1981, GEORGE and SHERRINGTON 1988, PreECE and SutTer 1991, UOSUKAINEN 1992). During the rooting process, problems may arise also from internal latent bacterial contaminants (Boxus and Terzi 1985, 1988, Constantine 1986, YeOMAn 1986, Poulsen 1988, LeIFERT et al. 1991, SAVEla and Uosukainen 1994). Also the quality and texture of the growth substrate and the thermohydrical stress influence the rooting and survival of rooted plantlets, particularly in direct rooting (Avanzato et al. 1993).

Good rooting techniques are needed to obtain plant material of uniform quality which, together with correct timing of AMF inoculation, are essential factors in AMF utilization. The aim of this study was to optimize these two steps and to minimize the effect of accidental external factors in AMF utilization.

\section{Material and methods}

The study consisted of four experiments. Apple rootstock YP, and two Finnish crab apple culti- vars, Hanna and Marjatta, were used in this study. All these cultivars are offspring of Malus baccata (L.) Moench. Both 'Hanna' and 'Marjatta' cultures consisted of one meristem clone, but in the YP experiments, two meristem clones (YP130 and YP-148) were used. Microcuttings were 26-35 mm long and harvested from a proliferation medium (UOSUKAINEN 1992) six weeks after subculture. In the first three experiments microcuttings were rooted in test tubes, size $22 \mathrm{~mm} \mathrm{x}$ $150 \mathrm{~mm}$, sealed with aluminium caps allowing gas exchange. An acute auxin treatment (LANE and McDougald 1982) for root induction was given by immersing the microcuttings in $100 \mathrm{mg} /$ 1 IBA 1:1 alcohol-water solution for $15 \mathrm{~min}$. During the root initiation phase microcuttings were on the hormone-free rooting medium (UOSUKAINEN 1992). Rooted microcuttings were transplanted to soil after 7 weeks. In experiment 4 , the direct rooting method, combined with a procedure of acute auxin treatment, was used. Shoots were dipped for $7 \mathrm{sec}$ in a water solution of $\mathrm{NaOH}$ $(0.5 \mathrm{~N})$ dissolved IBA $(100 \mathrm{mg} / \mathrm{l})$. After dipping the microcuttings were stuck directly in rooting substrate.

The AMF strains used as inoculants were Glomus claroideum Schenck \& Smith strain V43a (experiment 2), G. hoi Berch \& Trappe strains V98 (exps. 1 and 4) and V104 (exps. 1 and 2), G. mosseae (Nicol. \& Gerd.) Gerdemann \& Trappe strain V57 (exp. 4) and G. fistulosum Skou \& Jakobsen strains V92 (exp. 1), V107 (exp. 1) and V128 (exp. 4). The inoculum was a mixture of infected maize roots, hyphae, spores and growth substrate. As a control, a similar soil and root inoculum without AMF was used. Inocula $(1 \mathrm{ml} /$ microcutting) were placed in the planting hole prior to transplantation.

Root colonization by AM fungi was estimated at the end of the experiment 1 and at the end of the first repetition of the experiment 4 using the grid-line intersect method (GIOVANNETTI and Mosse 1980) for root samples stained in 0.05 acid fucsin according to KORMANIK and MCGRAW (1982). Statistical analyses were done using SAS, and means were separated by using the Duncan's Multiple Range Test. 
In YP experiment 1, the effects of fructose, glucose and sucrose (30 g/l), as carbohydrate source in the in vitro rooting medium, combined with AMF inoculation at transplanting to soil, on the survival and growth of 76 micropropagated YP plants were studied in a pot experiment with seven replicates. There were five mycorrhizal treatments: (1) uninoculated (No AMF), (2) inoculated with V92, (3) inoculated with V107, (4) inoculated with V98 and (5) inoculated with V104. Rooted, 7-week-old microcuttings were planted in 0.251 plastic Vefi pots containing a substrate mixture of steam sterilized peat and sand (3:1) limed with $4 \mathrm{~g} / \mathrm{l}$ Dolomite lime (Saxo oy, Finland) to give an approximate $\mathrm{pH}$ of 6 , and fertilized with $1.8 \mathrm{~g} / \mathrm{l}$ of the controlled-release fertilizer Osmocote Plus (8-9 months, 18N:11P:10K, Sierra Ltd, UK). The plants were transplanted to soil and inoculated on September 2, 1991. Plants were kept in continuous growth in a greenhouse for 34 weeks in long day. From October to March, plants were given artificial light (Philips HPI 400 $\mathrm{W})$. The daily temperature was $18^{\circ} \mathrm{C}$ during the light photoperiod and $15^{\circ} \mathrm{C}$ in the dark. The experiment was completed on April 24, 1992. Shoot height was recorded at 18 weeks, 24 weeks and 34 weeks after inoculation.

In YP experiment 2, the effect of AMF inoculation on the subsequent growth during the first two growing seasons of in vitro rooted YP microcuttings was studied in a pot experiment with 14 replicates. Rooted YP microcuttings, altogether 78 plants, originated from a rooting medium containing sucrose $30 \mathrm{~g} / \mathrm{l}$. There were four AMF treatmens: (1) uninoculated, (2) inoculated with V43a, (3) inoculated with V104 and (4) inoculated with a mixture of V43a and V104. Rooted microcuttings were planted in 0.251 plastic Vefi pots containing a substrate mixture of steam sterilized peat, sand and finesand $(1: 1: 1)$. The mixture was limed with $3 \mathrm{~g} / \mathrm{l}$ Dolomite lime ( $\mathrm{pH}$ of the mixture about 6 ) and fertilized with $0.5 \mathrm{~g} / \mathrm{l}$ of Osmocote Plus (8-9 months).

The rooted plantlets were transplanted to soil and inoculated on January 9, 1992. Plants were in continuous growth in the greenhouse until May 1992. The plants were kept in long day under artificial light (Philips SON-T Agro $400 \mathrm{~W}$ ) from January to March 1992. The daily temperature was $18^{\circ} \mathrm{C}$ during the light photoperiod and $15^{\circ} \mathrm{C}$ in the dark. In May 1992, the plants were replanted in 0.51 black plastic pots and kept outdoors from May to September 1992. At the beginning of October 1992, the plants were replanted in 21 plastic bag containers and stored at $4^{\circ} \mathrm{C}$ in the dark until the beginning of May 1993. After the cold storage, the plants were kept outdoors until October 11, 1993, whereafter the experiment was finished. During the first growing season, shoot heights were recorded 9 weeks after transplanting, on the second growing season, immediately after winter storage and again at the end of the season, 76 and 91 weeks after transplanting and inoculation, respectively. Also shoot base diameter was measured after 76 and 91 weeks, respectively.

In YP experiment 3, the optimal timing for transplanting microcuttings to soil was studied on apple rootstock YP. Rooting and survival were compared between microcuttings kept on hormone-free in vitro rooting medium for 0 (=direct rooting), 2, 3, 4 or 5 weeks before transplanting to soil. The experiment was repeated four times between June 1992 and January 1993. The rooting and weaning survival of 480-500 shoots in each treatment, altogether 2457 shoots, was estimated. The rooting rate was recorded before transplanting. Survival rates were estimated after two months in the greenhouse. Also $\mathrm{pH}$ of the rooting medium was measured during the in vitro rooting stage.

In crab apple experiment 4 , the effect of AMF inoculation on the rooting rate of crab apple cultivars Hanna and Marjatta was studied by using direct rooting with simultaneous AMF inoculation with three different AMF and a control inoculum. Inoculations with control (No AMF) and AMF V128 were repeated four times. Inoculations with AMF V57 and AMF V98 were repeated 3 and 2 times, respectively. Repetitions were started on February 18th, on April 20, on July 5 and on November 4 in 1993. Altogether $334 \mathrm{mi}-$ crocuttings of cv. Marjatta and 241 microcuttings of cv. Hanna were stuck. Steam sterilized rooting 
substrate, peat:sand:perlite $(4: 1: 5)$, consisted of peat (Vapo Peat XL/B0, Finland), sand (local, $0.5-1.5 \mathrm{~mm}$ ) and perlite (coarse, $3-5 \mathrm{~mm}$, Nordisk Perlite, Denmark). The substrate was fertilized with $1 \mathrm{~g} / \mathrm{l}$ Osmocote Plus (8-9 months) and Dolomite lime $5 \mathrm{~g} / \mathrm{l}$. Microcuttings were rooted in plant propagators (WARD Seed Tray $355 \mathrm{~mm}$ x $215 \mathrm{~mm}$ with Seed Tray Cover Ward Reg. Des. N:o 938270), one treatment/tray during rooting and weaning. Trays were placed for four weeks into a growth chamber. The light source consisted of a combination of fluorescent lamps (Warm White Super and Floralux), 3500 lux-3700 lux inside the propagators. The temperature during the rooting and weaning periods was $20^{\circ} \mathrm{C}$ during a 16-hour light period and $16-18^{\circ} \mathrm{C}$ during the 8-hour dark period. Rooting and weaning were estimated after four weeks.

After the rooting and weaning stage, subsequent growth of the microcuttings, which were transplanted to soil and inoculated with G. fistulosum V128 on February 18th, was also estimated. Two months after transplanting and inoculation, plant heights were measured, small plants were replanted in plastic pots $(12 \mathrm{~cm})$ and potted plants were placed in a randomized order on a table in the greenhouse. The potting substrate was similar to the rooting substrate. Plant heights were measured on May 6th, 2.7 months after inoculation, again on June 24th, during the most active growth, and finally in the autumn, on September 15 th, 7 months after transplanting to soil.

\section{Results}

In YP experiment 1, weaning survival of apple rootstock YP was highly dependent on the carbohydrate source of the in vitro rooting medium. After 18 weeks in the greenhouse, the weaning survival rate was $0 \%, 21.1 \%$ and $50 \%$ for fructose, glucose and sucrose, respectively. Due to the poor survival rates, the interactions between the carbohydrates and the mycorrhizal fungi were not recorded after the weaning stage.

AMF inoculation increased the mean shoot heights, especially at 24 and 34 weeks. This effect
Shoot height, $\mathrm{cm}$

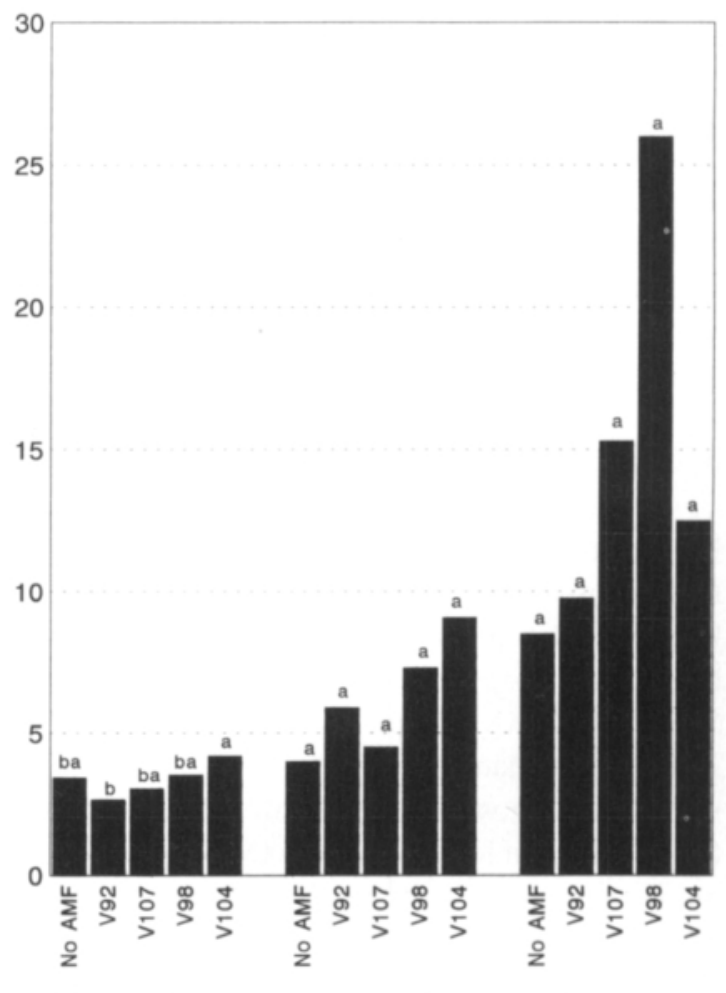

18 weeks

24 weeks

34 weeks

Fig. 1. Effect of arbuscular mycorrhizal (AMF) inoculation $(\mathrm{V} 92, \mathrm{~V} 107=G$. fistulosum; V98, V104 = G.hoi $)$ on shoot height of apple rootsock YP at three different times. For each time, values sharing the same letter do not differ at $\mathrm{p}=0.05$ according to Duncan's multiple range test. No $\mathrm{AMF}=$ non-inoculated control plants.

was, however, not statistically significant (Fig. 1). Plants inoculated with $G$. hoi V98 resulted eventually in 3 times higher plants than uninoculated ones. Also a higher rate of uninoculated plants lapsed into arrest of growth than inoculated plants, eventually (Table 1). At 18 weeks, $22 \%$ of uninoculated and $18 \%$ of inoculated plants were growing vigorously, being $>5 \mathrm{~cm}$ high. At 24 weeks, $12.5 \%$ of uninoculated and $22 \%$ of inoculated plants were $>10 \mathrm{~cm}$ high, at 34 weeks $12.5 \%$ and $55.5 \%$, respectively. At the end of the experiment, the AMF colonization in inoculated plants varied from $25 \%$ (V92) to $37.5 \%$ (V98) . Due to spread of AMF from adjacent pots, AMF colonization was $6.3 \%$ in the uninoculated plants. 
Table 1. Effect of arbuscular mycorrhizal (AMF) inoculation (V92, V107 = G.fistulosum; V104 = G. hoi) on the proportion ( $\%$, as means of 4-9 surviving plants) of apple rootstock YP plants in vigorous growth (i.e. plants $>100 \mathrm{~mm}$ ) in height, at 24 weeks and 34 weeks after onset of pot experiment. No $\mathrm{AMF}=$ non-inoculated control plants.

\begin{tabular}{lcccc}
\hline & \multicolumn{2}{c}{ Plants in vigorous growth, \% } & $\begin{array}{c}\text { Root } \\
\text { colonization, \% } \\
\text { Mycorrhizal }\end{array}$ \\
\cline { 2 - 4 } $\begin{array}{l}\text { treatment } \\
\text { treeks }\end{array}$ & 24 weeks & 34 weeks & 34 weeks \\
\hline No AMF & 22.2 & 12.5 & 12.5 & $6.3 \mathrm{~b}$ \\
V92 & 0 & 25.0 & 25.0 & $25.0 \mathrm{ba}$ \\
V107 & 25.0 & 0 & 40.0 & $30.0 \mathrm{a}$ \\
V98 & 33.3 & 20.0 & 100.0 & $37.5 \mathrm{a}$ \\
V104 & 14.3 & 42.9 & 57.1 & $26.4 \mathrm{ba}$ \\
Inoculated, & & & & \\
mean & 18.2 & 22.0 & 55.5 & 29.7 \\
\hline
\end{tabular}

The results from the YP experiment 2 are illustrated in Figure 2. After nine weeks, there was a significant growth increase in YP rootstocks due to inoculation with $G$. claroideum V43a. The other AMF strains also caused a mean growth increase, which was, however, not statistically significant. At 76 weeks, after cold storage and one month of new growth, the positive effects of inoculation had decreased. However, plants in the treament V43a + V104 were, on average, still bigger than plants in other treatments, but the differences were not statistically significant. Prior to cold storage, this treatment had the shortest plants. Plants inoculated with V104 alone were poor in growth after cold storage. There were only small differences in the stem base diameter between inoculated and uninoculated plants. After cold storage, V104 showed also the smallest stem base diameter which correlates with the poor growth in this treatment. The uninoculated treatment had the highest proportion of surviving plants throughout the experiment, the percentage being $86 \%$ at the end of the experiment. Corresponding percentages for the AMF treatments V43a, V104 and V43a+V104 were $57 \%, 29 \%$ and $64 \%$, respectively. Root infection was not evaluated in this experiment.

At 9 weeks, the proportion of plants in active growth (>10 $\mathrm{cm}$ high) was greater in all $\mathrm{AMF}$ treatments (Table 2) than in the control. At 76
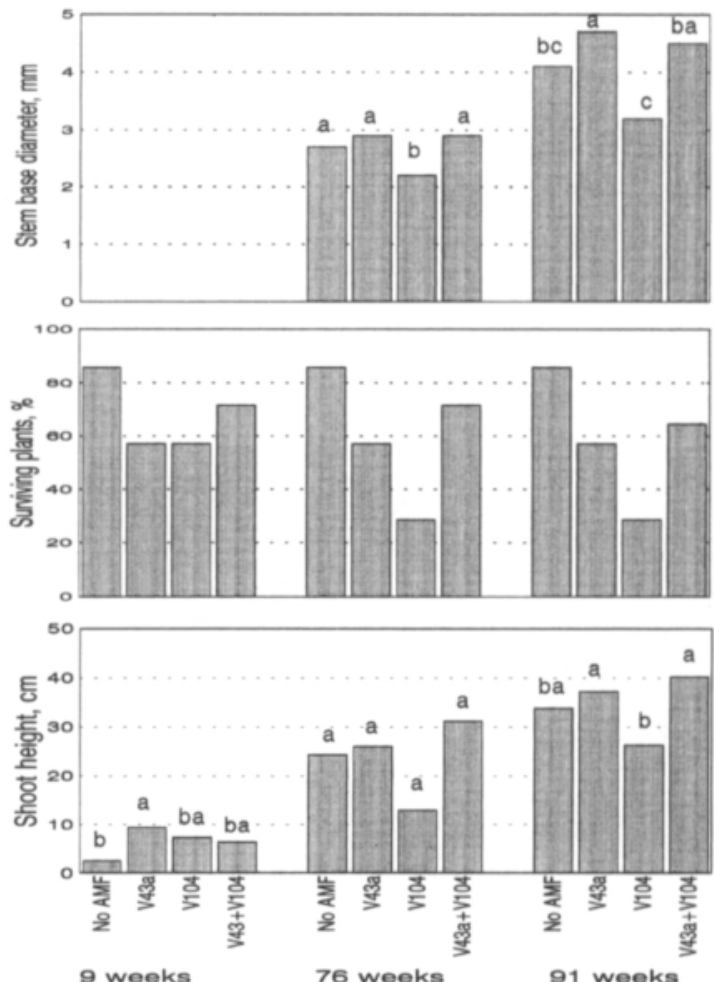

Fig. 2. Effect of arbuscular mycorrhizal (AMF) inoculation $(\mathrm{V} 43 \mathrm{a}=G$. claroideum, $\mathrm{V} 104=G$. hoi $)$ on shoot height, proportion of surviving plants and stem base diameter of apple rootstock YP at three different times. For each time, values sharing the same letter do not differ at $\mathrm{p}=0.05$ according to Duncan's multiple range test. No AMF $=$ non-inoculated control plants.

and 91 weeks, however, inoculation with $G$. hoi V104 had caused a strong growth retardation, while $100 \%$ of the plants inoculated with the combination of V43 and V104 were $>30 \mathrm{~cm}$ high, eventually.

In YP experiment 3, the roots started to emerge after 10 days on the in vitro rooting medium. The mean rooting rate of microcuttings at transplanting and the mean weaning survival of the same plantlets after 2 months in the greenhouse showed negative correlation (Fig. 3). Microcuttings that had been on the in vitro rooting medium for 5 weeks had the highest mean rooting rate, $41 \%$, but the mean survival rate was only $27 \%$. Directly rooted microcuttings had the highest mean survival rate, $73.3 \%$. Although there was seasonal 


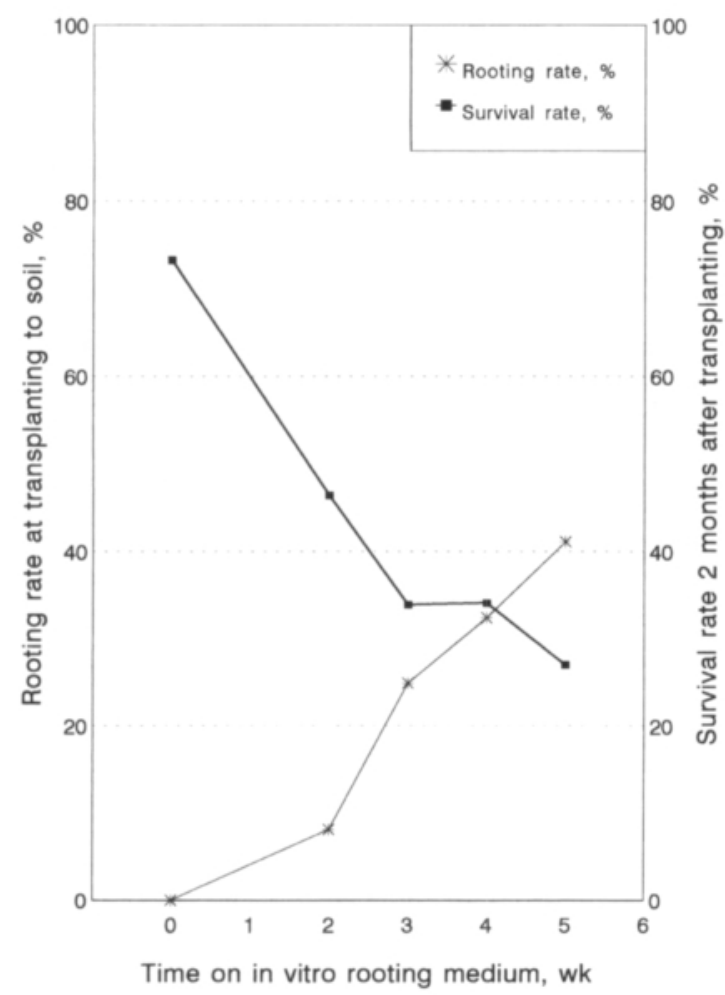

Fig. 3. Effect of length of in vitro rooting phase (wk) on rooting and survival rates (\%) of apple rootstock YP microcuttings. Rooting rates were estimated at transplanting to soil and survival rates 2 months after transplanting.

variation in percentual rates between repetitions, the rooting rates correlated with the survival rates. In visual observation, an increasing number of symptoms resembling nutritional deficiency was recorded in the microcuttings during the in vitro

Table 2. Effect of arbuscular mycorrhizal (AMF) inoculation $(\mathrm{V} 43 \mathrm{a}=\mathrm{G}$. claroideum; V104 = G. hoi) on the proportions (\%, as means of 4-12 surviving plants) of apple rootstock YP plants in vigorous growth, i.e. $>100 \mathrm{~mm}$ high at 9 weeks, $>250 \mathrm{~mm}$ at 76 weeks and $>300 \mathrm{~mm}$ at 91 weeks after onset of pot experiment. No AMF $=$ noninoculated control plants.

\begin{tabular}{lccc}
\hline & \multicolumn{3}{c}{ Plants in vigorous growth, \% } \\
\cline { 2 - 4 } AMF treatment & 9 weeks & 76 weeks & 91 weeks \\
\hline No AMF & 0.0 & 41.7 & 58.3 \\
V43a & 37.5 & 37.5 & 75.0 \\
V104 & 28.6 & 0.0 & 25.0 \\
V43+V104 & 22.2 & 77.7 & 100.0 \\
\hline
\end{tabular}

Proportion of growing plants, \%

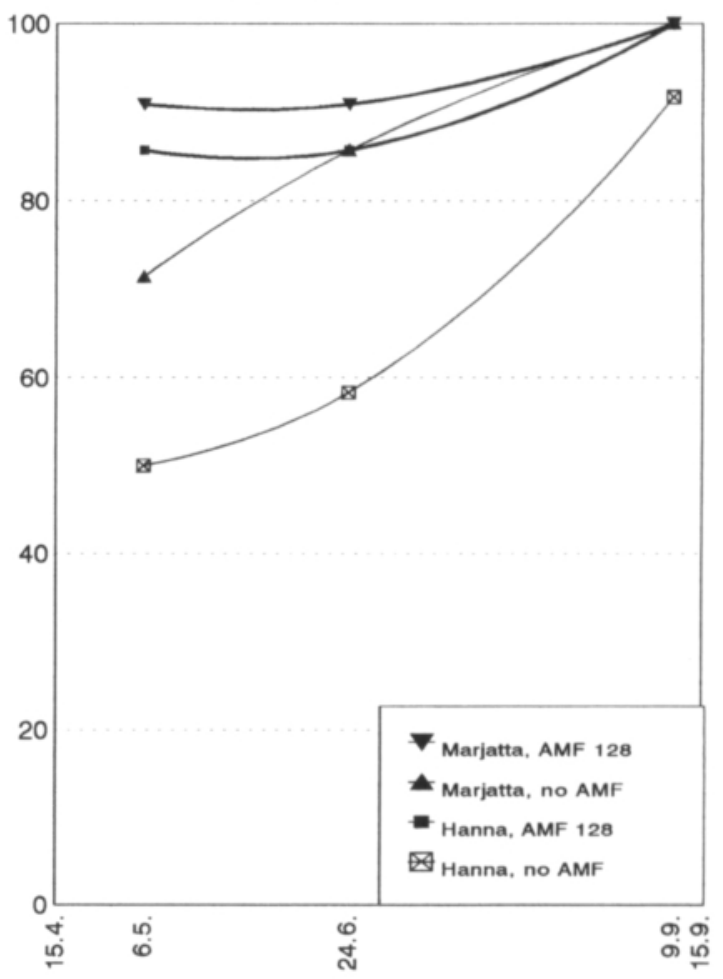

Date, day-month

Fig. 4. Effect of arbuscular mycorrhizal (AMF) inoculation $(\mathrm{V} 128=G$. fistulosum $)$ on the continuous growth of directly rooted microcuttings of crab apple cultivars Marjatta and Hanna. No AMF = non- inoculated control plants. The proportion of growing plants (\%) after the rooting and weaning stage was estimated on May 6, June 24 and September 9 in 1993.

rooting. The $\mathrm{pH}$ value of the in vitro rooting medium rose during the 5 - week period from 4.9 to 6.3 .

According to the results obtained from crab apple experiment 4 , AMF inoculation did not improve the rooting rate in direct rooting (Table 3). Malus cultivars differed in their reaction to different AMF. Particularly AMF V98 seemed to be incompatible with cv. Hanna. In visual observation, at the end of the rooting stage, the uninoculated plantlets seemed to be more vital than the inoculated ones. Most of the inoculated plants had dry or pale green leaves often with a tinge of red. These symptoms were transient in their na- 


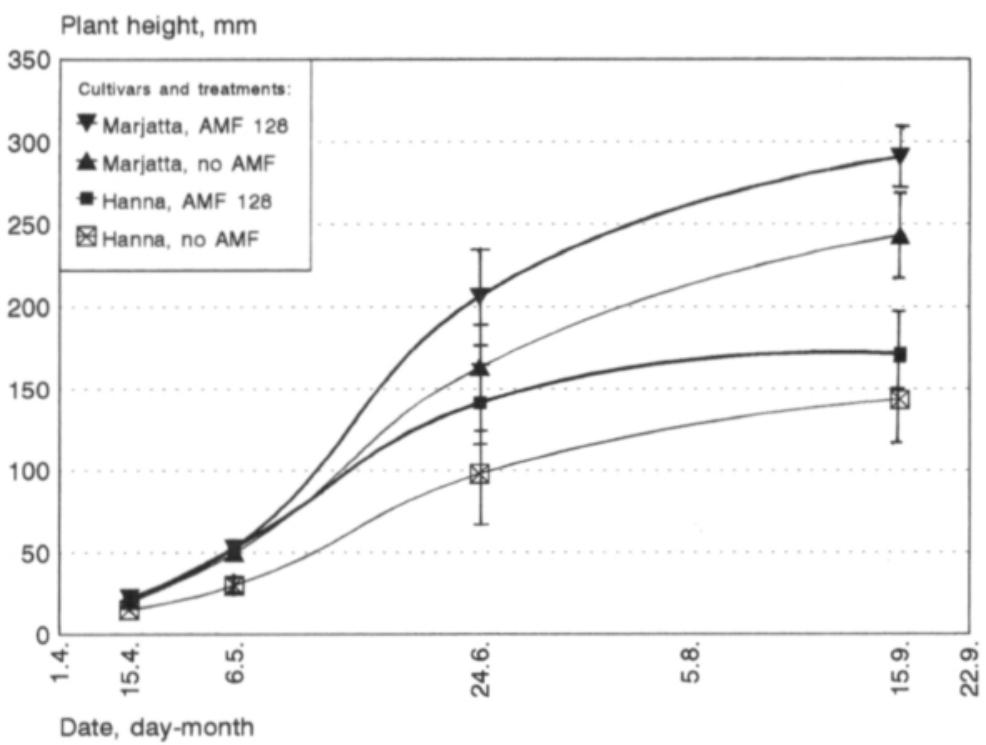

Fig. 5. Effect of arbuscular mycorrhizal (AMF) inoculation $(\mathrm{V} 128=G$. fistulosum $)$ on the growth of micropropagated crab apple cultivars Marjatta and Hanna. No AMF = non-inoculated control plants. The plant height (mm) was measured on April 15, May 6, June 24 and September 15.

ture and resembled symptoms caused by nutritional deficiencies.

The plantlets, inoculated with G. fistulosum $\mathrm{V} 128$, continued their growth and development soon after the weaning stage. The uninoculated plants, instead, had a great tendency to lapse into

Table 3. Effect of arbuscular mycorrhizal (AMF) inoculation on rooting rate $(\%)$ of direct rooted microcuttings of crabapple cultivars Marjatta and Hanna, recorded four weeks after inoculation and transplanting to soil. Inoculation treatments (AMF V57 = G. mosseae; AMF V98 = G. hoi; $A M F$ V128 = G. fistulosum and No AMF = no inoculation, given to coincide with transplanting to soil), total number of treated microcuttings and rooting rate ( $\%$, as means of 4 repetitions).

\begin{tabular}{llcc}
\hline Cultivar & Treatment & $\begin{array}{c}\text { Number of } \\
\text { microcuttings }\end{array}$ & $\begin{array}{c}\text { Rooting } \\
\text { rate, \% }\end{array}$ \\
\hline Marjatta & No AMF & 103 & 77.7 \\
Marjatta & AMF V57 & 73 & 80.8 \\
Marjatta & AMF V98 & 58 & 69.0 \\
Marjatta & AMF V128 & 100 & 65.0 \\
Hanna & No AMF & 75 & 66.7 \\
Hanna & AMF V57 & 55 & 63.6 \\
Hanna & AMF V98 & 40 & 30.0 \\
Hanna & AMF V128 & 71 & 77.5 \\
\hline
\end{tabular}

arrest of growth (Fig. 4). The greatest difference was observed 2.7 months after inoculation and transplanting to soil. At that point, on May 6th, approximately $90 \%$ of inoculated plants had started active growth. However, at the same time only about $60 \%$ of uninoculated plants were in active growth. Even 4 months after transplanting and inoculation, only $58.3 \%$ of uninoculated 'Hanna' plants had started to grow in height. After 7 months, on September 15 th, $8.3 \%$ of uninoculated 'Hanna' plants had remained at the stage of dormancy.

The growth curves of directly rooted and $G$. fistulosum V128 inoculated 'Marjatta' and 'Hanna' plants (Fig. 5) illustrate that the inoculated plants were, throughout the growing season, at least $19 \%$ higher than the uninoculated plants. However, the difference in growth was statistically significant only in cv. Hanna, on May 6th, 2.7 months after transplanting to soil. At that point the inoculated 'Hanna' plants were $76 \%$ higher than the uninoculated plants. The major differences in growth decreased towards the end of the growing season. Only sporadic AMF root colonization was observed after 4 or 7 months despite a 
moderate to abundant sporulation in cv. Marjatta and a moderate sporulation in cv. Hanna.

\section{Discussion}

The experiments conducted with apple rootstock YP and crab apple cultivars Hanna and Marjatta show both a negative and a positive effect from inoculation of AMF fungi at the beginning of the weaning stage of the microcuttings. Of the positive effects, increased growth as a result of inoculation with Glomus claroideum V43a, G. fistulosum V128 and G. hoi V98 can be mentioned. Most of the AMF inoculated plantlets obtained continuous normal growth soon after the weaning stage, but growth lapses of several months were common in uninoculated plantlets. Therefore, the inoculated plants were more uniform at the end of the growing season. From a practical point of view, this means a great benefit for the nursery: due to the balanced growth, the majority of the plantlets can be sized into one class. AMF inoculation can be profitable to nurseries also due to the shorter time needed for raising the plantlets to saleable trees. According to our results, the culture time may be a quarter to one third shorter than with uninoculated plants.

In apple, the benefits of early inoculation of micropropagated plantlets should be re-evaluated. In direct rooting of microcuttings, AMF inoculation did not give such a positive effect on rooting as has been reported on bigger cuttings (JOHNSON et al. 1980, GNEKOW and MARSCHNER 1989). On the contrary, G. hoi V98 seemed to be incompatible with crab apple 'Hanna', causing severe rotting of the microcuttings. A similar negative effect of AMF inoculation on Malus microcuttings in direct rooting was also observed by Avanzato et al. (1994) using G. mosseae as the inoculant. The poor general condition of the inoculated microcuttings after the rooting and weaning stage, possibly due to nutritional deficiencies, may be caused by too rapid and intense root colonization by the AM fungi.

AMF inoculation of in vitro rooted plantlets simultaneously with transplanting to soil did not seem to be beneficial, either. As a rule, in on agar rooted microcuttings, most AMF-host combinations resulted in lower survival rates during plant establishment to soil than no inoculation. Strains belonging to the species $G$. hoi, in particular, seemed to cause severe rotting of the plantlets. In the present study, the rotting of microcuttings and micropropagated plantlets was probably not caused by a pathogen, because (i) the control plants were inoculated with the same soil inoculum but without $\mathrm{AMF}$, (ii) some AMF strains gave better rooting results than others and caused only little or no rotting, (iii), rotting occurred slowly, after three weeks. Thus the rotting did not start until the roots had emerged and root growth had started. Bacterial contaminants that cause rotting of microcuttings (Boxus and TerZI 1985, 1988, Constantine 1986, YeOMAn 1986, Poulsen 1988, LEIFERT et al. 1991, SAVEla and UosukaineN 1994) appear virulent earlier and are more acute in their nature. Apple microcuttings need about 4 weeks to develope a good root system and they seem to change to fully autotrophic nutrition slowly. During this period plantlets normally release more $\mathrm{CO}_{2}$ than they are capable to assimilate through photosynthesis (GEORGE and SHERRINGTON 1988). It is therefore concluded that the rotting of the microcuttings was actually caused by the mycorrhizal fungi. Infection with AMF during the early acclimatization phase probably led to a carbon drain which was not compensated for by the plant during the prevailing stress conditions. Carbon drain is a phenomenon not uncommon in mycorrhizal experiments. GNEKOW and MARSCHNER (1989) suggested that carbon drain takes place in AMF inoculated apple cuttings in a field situation at high P levels.

It is a well-known fact that Malus microcuttings are extremely sensitive to environmental stresses (Dirr and Heuser 1987, Avanzato et al. 1993). The adaptation to post vitro conditions, as such, is an extreme stress to a small plantlet due to a high energy requirement. Therefore, AMF inoculation may become an overwhelming stress for a small apple microcutting at the rooting and weaning stage. If the small plantlet, often in poor nutritional and hormonal balance, is sub- 
mitted simultaneously to another extreme stress, such as AMF infection, the result may be a hostparasite relationship instead of a symbiosis.

According to Avanzato et al. (1994), the rotting might have been due to some pathogen in the inoculum. To overcome the rotting problem, he suggests that the inoculum should be applied as sterilized spores. In France, RAvolaniRINA et al. (1989) have developed a method of using surface sterilized AMF spores in combination with a post vitro rooting procedure. Besides pathogens, there is also a risk of insect pests, and therefore it is equally important to control the sanitary status of AMF inoculum as it is to control the phytosanitary status of plant material (CASSELLS 1991).

Referring to the above, the importance of an optimal rooting method and the correct timing of inoculation must be emphasized. The carbohydrate source of the rooting medium has a great effect on the in vitro rooting of apple microcuttings (Moncousin et al. 1992). Rooting experiments conducted with apple cv. Compact Spartan showed that sucrose was an indispensable component in the agar gelified rooting medium ( $\mathrm{P}$. Druart, pers. commun.). UOSUKAINEN (1992) showed that both sucrose and glucose in the rooting medium, combined with optimal auxin treatment, resulted in a high rooting rate with apple rootstock YP. The present study showed that the carbohydrate source of the rooting medium has also a great effect on weaning survival of the microcuttings, when in vitro rooted plantlets are used. The highest weaning and survival rates of inoculated rooted plantlets were obtained by using sucrose in in vitro rooting medium.

Macronutrients are important to root induction, root emergence and root growth, but high salt levels, high nitrogen levels in particular, are frequently inhibitory to root initiation (GEORGE and SHERRINGTON 1988). Rooting experiments with the apple cv. Compact Spartan showed that $\mathrm{NH}_{4} \mathrm{NO}_{3}$ was an inhibitor of root emergence and further growth. Decreases in average root number/ plantlet, smaller roots and a lower rooting rate were typical. On the other hand, the macronutrients $\mathrm{KH}_{2} \mathrm{PO}_{4}$ and, particularly, $\mathrm{Ca}\left(\mathrm{NO}_{3}\right)^{2}$ stimulated root growth (P. Druart, pers. commun.). However, maximum AMF root colonization and sporulation occur in soil of low fertility. Both phosphorus and nitrogen may significantly reduce root colonization if present at high levels and there exists a balance between these two elements (DANIEls Hetrick 1986). Thus, there is a contradiction between the optimal conditions for rooting and AMF root colonization. This contradiction can most likely be reconciled only by using intermediate conditions rather than optimal conditions for one or the other partner of the symbiosis. For example, AMF inoculation after the weaning stage, instead of immediately after the in vitro stage, may give a more positive growth response, as was found by AzCON-AguILAR (1994) in Annona cherimola. The level of mineral nutrients in the weaning substrate also needs to be modified to meet the requirements of the developing root systems and undisturbed growth of apple microcuttings. These elements must be further examined and their effects must be controllable before AMF inoculation can be introduced to nursery men.

Acknowledgements. We are grateful to the Ministery of Agriculture and Forestry for the financial support of this study. We wish to express our special thanks to Mrs. Anja Manninen, laboratory technician Pirkko Jalkanen and agricultural engineer Leena Eerola, for their skilful technical assistance.

\section{References}

An, Z. Q., Shen, T. \& WANG, H.G. 1993. Mycorrhizal fungi in relation to growth and mineral nutrition of apple seedlings. Scientia Horticulturae 54: 275-285.

Avanzato, D., Cherubini, S. \& Jaque, E. 1993. Portainjertos de manzano de obtención in vitro. Potencialidad de la aclimatación y enraizamiento directo de estaquillas. Hortofruticultura 1: 67-72.
- Cherubini, S., Dominici, A.L., Liberali, M. \& SperANZA, S. 1994. Preliminary trials on direct rooting of apple microcuttings ex vitro inoculated with Glomus mosseae and Azospirillum brasilense. BRIDGE. Commission of the European Communities. COST 8.10 Vesicular Arbuscular Mycorrhizas. Report of 1993 activities. p. 64-65. 
Azcon-Aguilar, C., Encina, C. L., Azcon, R. \& Barea, J. M. 1994. Effect of arbuscular mycorrhiza on growth and development of Annona cherimola micropropagated plants. Agricultural Science in Finland 3: (In press).

Benson, N. R. \& Covey, R. P. 1976. Response of apple seedlings to zinc fertilization and mycorrhizal inoculation. HortScience 11: 252-253.

Boxus, P. \& Terzi, J. M. 1985. Big losses due to bacterial contaminations can be avoided in mass propagation scheme. Acta Horticulturae 212, 1: 91-93.

- \& TerzI, J. M. 1988. Control of accidental contaminations during mass propagation. Acta Horticulturae 225: 189-191.

Branzanti, B., Gianinazzi-Pearson, V. \& Gianinazzi, S. 1992. Influence of phosphate fertilization on the growth and nutrient status of micropropagated apple infected with endomycorrhizal fungi during the weaning stage. Agronomie 12: 841-845.

Cassells, A. C. 1991. Problems in tissue culture: culture contamination. In: Debergh, P. C. \& Zimmerman, R. H. (eds.). Micropropagation. Kluwer Academic Publishers, Dordrecht, Boston, London. p. 31-44.

Constantine, D. R. 1986. Micropropagation in the commercial environment. In: Whithers, L. A. \& Alderson, P. G. (eds.). Plant Tissue Culture and its Agricultural Applications. Butterworths, London, Boston, Durban, Singapore, Sydney, Toronto, Wellington. p. 175-186.

DANIELS HeTrick, B. A. 1986. Ecology of VA mycorrhizal fungi. In: Powell, C. L. \& Bagyaraj, D. J. (eds.). VA Mycocorrhiza. CRC Press, Boca Raton, Florida. p. 3555.

Debergh, P. C. \& Maene, L. J. 1981. A scheme for commercial propagation of ornamental plants by tissue culture. Scientia Horticulturae 14: 335-345.

De Klerk, G. J. \& Ter Brugge, J. 1992. Factors affecting adventitious root formation in microcuttings of Malus. Agronomie 12: 747-755.

Denissen, C. J. M., De Klerk, G. J., Albers, M. R. J., Ter Brugge, J. \& Kunneman, B. P. A. M. 1992. Effect of accidental factors on rooting of Malus Golden Delicious. Agronomie 12: 799-802.

DirR, M. A. \& Heuser, C. W. JR. 1987. The Reference Manual of Woody Plant Propagation. From Seed to Tissue Culture. 239 p. Varsity Press, Athens, Georgia.

George, E. F. \& Sherrington, P. D. 1988. Plant Propagation by Tissue Culture. Handbook and Directory of Commercial Laboratories. 709 p. Repr. Exegetics Ltd. Westbury.

Gianinazzi, S., Gianinazzi-Pearson, V. \& Trouvelot, A. 1990. Potentialities and procedures for the use of endomycorrhizas with special emphasis on high value crops. In: Whipps, J.M. \& Lumsden, B. (eds.). Biotechnology of Fungi for Improving Plant Growth. Cambridge University Press, Cambridge. p. 41-54.

GiovanetTI, M. \& Mosse, B. 1980. An Evaluation of Techniques for Measuring Vesicular-Arbuscular Mycorrhizal Infection in Roots. 618 p. Academic Press. London.
Gnekow, M. A. \& Marchner, H. 1989. Role of VA-mycorrhiza in growth and mineral nutrition of apple (Malus pumila var. domestica) rootstock cuttings. Plant \& Soil 119: 285-293.

Harley, J. L. \& Smith, S. E. 1983. Mycorrhizal Symbiosis. 483 p. Academic Press, London and New York.

Hoepfner, E. F., Koch, L. B. \& Covey, R. P. 1983. Enhancement of growth and phosphorous concentrations in apple seedlings by vesicular-arbuscular mycorrhizae. Journal of American Society for Horticultural Science 108: 207-209.

Johnson, C. R., JoIner, J. N. \& Crews, C. E. 1980. Effects of $\mathrm{N}, \mathrm{K}$ and $\mathrm{Mg}$ on growth and leaf nutrient composition of three container grown woody ornamentals inoculated with mycorrhizae. Journal of American Society for Horticultural Science 105: 286.

KormaniC, P. P. \& MCGRaW, A.-C. 1982. Quantification of vesicular arbuscular mycorrhizae in plant roots. In: Schenk, N. C. (ed.). Methods and Principles in Mycorrhizal Research. The American Phytopathological Society. St. Paul, Minnesota. p. 37-45.

Lane, W. D. \& Mcdougald, J. M. 1982. Shoot tissue culture of apple: Comparative response of five cultivars to cytokinin and auxin. Canadian Journal of Plant Science 62: 689-694.

Leifert, C., Ritchie, J. \& Waites, W. M. 1991. Contaminants of plant tissue and cell cultures. World Journal of Microbiology and Biotechnology 7: 452-469.

Moncousin, C., Ribaux, M., O'rourge, J. \& Gavillet, S. 1992. Effects of type of carbohydrate during proliferation and rooting of microcuttings of Malus Jork 9. Agronomie 12: 775-781.

MossE, B. 1973. Advances in the study of vesicular-arbuscular mycorrhizae. Annual Review of Phytopathology 11: 171-196.

Plenchette, C., Furlan, V. \& Fortin, J. A. 1981. Growth stimulation of apple trees in unsterilized soil under field conditions with VA mycorrhiza inoculum. Canadian Journal of Botany 59: 2003-2008.

Poulsen, G. B. 1988. Elimination of contaminating micro-organisms from meristem culture of apple rootstock M26. Acta Horticulturae 225: 193-197.

Preece, J. E. \& Sutter, E. G. 1991. Acclimatization of micropropagated plants to the greenhouse and field. In: Debergh, P.C. \& Zimmerman, R. H., (eds.). Micropropagation. Kluwer Academic Publishers, Dordrecht, Boston, London. p. 71-93.

Ravolanirina, F., Blal, B., Gianinazzi, S. \& GianinazZI-PEARSON, V. 1989. Mise au point methode rapide d'endomycorhization de vitroplants. Fruits 44: 165170.

Savela, M. \& Uosukainen, M. 1993. Characterization of bacteria contaminating tissue cultures of apple rootstock YP. Journal of Applied Bacteriology 76: 368376.

UOSUKAINEN, M. 1992. Rooting and weaning of apple rootstock YP. Agronomie 12: 803-806.

Yeoman, M. M. 1986. The present development and future of plant cell and tissue culture in agriculture, for- 
estry and horticulture. In: Whithers, L.A. \& Alderson, P.G. (eds.). Plant Tissue Culture and its Agricultural Applications. Butterworths, London, Boston, Durban, Singapore, Sydney, Toronto, Wellington. p. 175-186.

Zimmerman, R. H. \& Fordham, I, 1985. Simplified meth- od for rooting apple cultivars in vitro. Journal of American Society for Horticultural Science 110: 34-38.

Manuscript received February 1994

\title{
SELOSTUS
}

\section{Arbuskeli-mykorritsasiirrostuksen vaikutus mikrolisättyjen omenapuiden (Malus) juurtumiseen, viljelyolosuhteisiin sopeutumiseen ja sopeutumisvaiheen jälkeiseen kasvuun}

\author{
Marjatta Uosukainen ja Mauritz Vestberg
}

Maatalouden tutkimuskeskus

Maatalouden tutkimuskeskuksen Laukaan tutkimus- ja valiotaimiasemalla tutkittiin eri juurrutusmenetelmien sekä arbuskelimykorritsa- eli AMF- siirrostuksen vaikutuksia omenapuun mikropistokkaiden juurtumiseen, kasvihuoneviljelyyn sopeuttamiseen ja sopeuttamisen jälkeiseen kasvuun. Tutkimuksen tavoitteena oli optimoida sekä juurrutus- että siirrostusolosuhteet siten, että satunnaisten tekijöiden häiritsevä vaikutus saataisiin mahdollisimman vähäiseksi ja toisaalta mykorritsasymbioosista saatava hyöty mahdollisimman suureksi.

Tutkimus toteutettiin neljänä kokeena. Koekasveina olivat omenapuun perusrunko YP sekä suomalaiset koristeomenapuut 'Hanna' ja 'Marjatta'. Tutkittaessa kasvien selviytymistä kasvihuoneviljelyyn sopeuttamisvaiheesta todettiin, että in vitro-juurrutusalustan hiilihydraattilähteenä sakkaroosi paransi kasvien selviytymistä verrattaessa glukoosi- ja fruktoosipitoisilla alustoilla juurrutettuihin versoihin. Paras juurrutus- ja sopeuttamistulos saatiin kuitenkin juurruttamalla mikropistokkaat suoraan turvepohjaisella kasvualustalla in vitro-juurrutuksen sijasta. AMF- siirrostus ei parantanut juurtuvuutta suorajuurrutuksessa. Glomus hoi kanta V98 aiheutti vaikea-asteista mikropistokkaiden tyvien mätänemistä ja täten jopa heikensi 'Hanna'-lajikkeen juurtuvuutta. AMF-siirrostus kuitenkin lisäsi juurtuneiden kasvien keskimääräistä verson tuorepainoa, erityisesti siirrostus kannoilla $G$. hoi V98, G. claroideum V43a tai $G$. fistulosum V128. Tämä vaikutus vaihteli huomattavasti eri isäntä-sieniyhdistelmissä, ja mm. AMFkanta $G$. hoi V104 jopa heikensi YP-perusrungon pikkutaimien kasvua. Omenapuun mikropistokkaille oli tyypillistä, että taimien kasvu pysähtyi juurrutus- ja sopeuttamisvaiheiden jälkeen. Sekä YP- perusrungon että koristeomenapuiden AMF-siirrostetuilla taimilla tämä ilmiö jăi selvästi harvinaisemmaksi kuin siirrostamattomilla taimilla.

Tasalaatuinen taimiaines, optimaalinen AMF-siirrostuksen ajankohta sekä juurrutus- ja sopeuttamisvaiheessa käytettyjen kasvualustojen ravinnetaso ovat onnistuneen tuloksen kannalta kriittiset tekijät. Näiden tekijöiden vaikutukset on hallittava ennenkuin AMF-siirrostuksella saadaan aikaan toimiva symbioosi. 